\title{
Você sabe? A narradora não. Um projeto literário para crianças: A mulher que matou os peixes, de Clarice Lispector
}

\section{Do you know? The narrator does not. A literary project for children: A mulher que matou os peixes, Clarice Lispector.}

Carlos Pires é Mestre e Doutorando em Letras pela Universidade de São Paulo (USP) e professor do Instituto Superior de Ensino Vera Cruz (ISE Vera Cruz) nos cursos "Formação de escritores" e "Alfabetização".

Contato: pirescarlos@gmail.com

Rafaella Natalício é educadora com pós-graduação no curso "Alfabetização: relações entre ensino e aprendizagem" (ISE Vera Cruz).

Contato: rafaellanatalicio@bol.com.br

Renata Grinfeld é educadora, com formação em Psicologia (USP) e Pedagogia (Instituto Singularidades) e especialização no curso "Alfabetização: relações entre ensino e aprendizagem"(ISE Vera Cruz), onde realizou a monografia "Uma análise do livro A mulher que matou os peixes de Clarice Lispector". Atualmente realiza um mestrado em Psicologia Educacional na Universidade de Buenos Aires e trabalha com formação docente do Projeto Trilhas no município de São Paulo.

Contato: regrinfeld@yahoo.com.br

A literatura infantil de Clarice Lispector possui uma interessante dimensão didática que se diferencia da maior parte dos livros produzidos para crianças. A autora apresenta personagens e situações que, de algum modo, podem parecer semelhantes aos 
contos de fada ou outras histórias infantis. Mas na mesma medida em que abre sua construção literária em direção a essa tradição, ela retira, por outro lado, qualquer fantasia muito imediata. 0 cachorro Ulisses, em Quase de verdade, narra latindo para sua dona, a própria Clarice, que, por sua vez, entende ou interpreta os latidos e bate tais histórias em sua máquina de escrever.

Em $A$ mulher que matou os peixes, a autora intensifica essa direção contrária à fantasia, ou que busca outra chave para que ela aconteça no presente das crianças, a ponto de fazer uma construção literária na qual mobiliza o que parece ser sua própria experiência de vida, criando estratégias particulares para envolver os leitores na trama. 0 começo da história desarma qualquer sedução imediata presente em muitos livros para crianças, de suspense ou mistério, que amarram a atenção por meio de algo que se revelará no percurso da leitura: "Essa mulher que matou os peixes infelizmente sou eu" (informar número de página). Revelar de saída o mistério do livro é só a primeira jogada dessa hábil narradora moderna que, em diversos momentos, como em 0 mistério do coelho pensante, admite de maneira franca não saber muita coisa da própria história que conta: "É verdade que nem eu, que estou contando a história, conheço a resposta"(informar referência).

Nos contos de fada, importantes alicerces da tradição de histórias para jovens e crianças, a atenção é capturada pela maneira como um mundo mágico revela-se ao leitor por meio de um narrador que tudo sabe, inclusive as intenções mais íntimas de cada personagem. Essas histórias, como se sabe, muitas vezes trazem lições de moral e ensinamentos que ganham maior estatuto de verdade justamente por serem apresentados por um narrador confiável, que reflete sobre uma experiência de vida. Clarice Lispector cria um espaço também para a fantasia, mas esta não adquire contornos mágicos, como na maioria dos contos de fada.

Em A mulher que matou os peixes, a atenção das crianças é presa por meio de estratégias de sedução lançadas sem rodeios, revelando um estilo de literatura infantil muito particular e rico. A autora constrói a situação literária como um diálogo imediato com as crianças e, durante o livro, aborda medos, angústias e dúvidas pertencentes aos mundos infantil e adulto a partir de um exercício bastante singular da imaginação. Clarice relata de maneira simples fatos complexos em que considera as diferentes perspectivas que aparecem sem qualquer espaço para maniqueísmos. A autora parece entender que a criança é diferente do adulto, o 
que não resulta, por sua vez, em uma construção infantilizada ou pouco complexa. Ela procura, a todo momento, uma maneira de considerar a realidade e a fantasia sem banalizá-las.

Problemas sérios como morte, doenças, medos, separações etc. são tratados frontalmente e, ao mesmo tempo, de maneira acolhedora, de modo que a criança consiga criar um espaço interno para elaborar esses temas supostamente difíceis de serem abordados. Possibilitar essa conversa entre o que a narradora conta e as experiências pessoais do leitor talvez seja o centro da construção literária infantil de Clarice Lispector, o que nos permite vislumbrar uma concepção de infância bastante fina e particular que, resumidamente, pode ser definida em duas palavras: empatia e respeito.

\section{REFERÊNCIAS}

LISPECTOR, Clarice. A mulher que matou os peixes. Rio de Janeiro: Rocco, 1999. 